\title{
Lignocellulosic Recycled Materials to Design Molded Products: Optimization of Physical and Mechanical Properties
}

\author{
Yanina Susel Aguerre* and Graciela Beatriz Gavazzo \\ Pulp and Paper Program (PROCYP) - Institute of Materials of Misiones (IMAM), Execution Unit of the National Council of \\ Scientific and Technical Research (CONICET) - National University of Misiones (UNaM), Posadas 3300, Argentina
}

\begin{abstract}
The object is to contribute to the reduction of environmental pollution, by reusing a fraction of urban solid waste, forestry and agroindustrial waste: newspaper (ONP), office paper (OWP), corrugated cardboard (OCC), pine sawdust, eucalyptus sawdust and sugar cane bagasse as raw material to design biocontainers suitable for growing plants, by applying pulp molding technology. The purpose is to evaluate the effects of the combination of these lignocellulosic materials on the physical-mechanical properties and optimize responses in order to select an ideal mixture on basis the product's necessities. An experimental design of type mixture of extreme vertices was followed, considering secondary fibers as base material, in a 0-100\% proportion, and pine sawdust, eucalyptus sawdust and bagasse fibers as reinforcement, in a $0-40 \%$ proportion. An experimental matrix by each reinforcing material was proposed. Properties were evaluated: density, tensile, bursting, tearing, compression, stiffness, wet tensile, permeability and water retention, testing handsheets weighing $150 \mathrm{~g} / \mathrm{m}^{2}$. Responses were optimized using a statistical program. It was found that OWP pulps increase strength properties; OCC pulps increases tear and wet tensile; ONP pulps increase stiffness and reinforcement materials increase permeability. Factors that allow reaching the objectives are a mixture of pulp OWP/OCC in a 50/50 proportion.
\end{abstract}

Key words: Lignocellulosic recycled materials, molded products, biodegradable containers, physical-mechanical properties, optimization.

\section{Introduction}

In the last decades, the high concentration of population in urban areas and the increasing level of development and industrialization have greatly increased the production of urban solid waste, forestry and agroindustrial waste. These residues usually end up in landfills or are burned in the open, causing serious problems of environmental pollution. Given this reality the need arises to develop a strategy to enhance the use of these wastes, giving added value to them. An alternative is to re-use these recycled lignocellulosic materials as raw material to design

\footnotetext{
*Correspondence author: Yanina Susel Aguerre, chemical engineer, Ph.D. student progress in National University of Misiones, research in Institute of Materials of Misiones (CONICET-UNaM), research fields: pulp and paper, recycled materials and biocontainers.
}

biodegradable containers suitable for growing plants.

Biodegradable containers are known as those containers made without pollutant materials derived from petroleum, which decompose rapidly when they are buried in soil or when they are composted [1]. The biocontainers are usually classified as plantables or compostables [2, 3]. The "plantable" containers are those that can be planted directly in the final container or in the field or seedbed; The plant roots can go through container walls, and once buried, they are biodegraded within a short period of time. The “compostables" containers are those that cannot be planted directly in the soil because the roots cannot go through container walls and their biodegradation is very slow, therefore, they must be removed and subjected to aerobic biological decomposition treatment $[4,5]$.

In recent times, the use of fibrous materials was 
increased, for example, rice hulls, recycled paper, peat, wood fiber, rice straw and coconut fiber, inter alia, as main raw material for making biocontainers [1, $2,6,7]$. A peat container usually in mixtures with paper waste or wood fiber waste is the most common plantable biocontainer, and the container of rice hull is the most common compostable biocontainer [3].

Generally, the research on biocontainers is focused on fungal growth on the walls, moisture loss substrate-container assembly, dry and wet strength and influence on plant growth [1-3, 8-10].

The best container will depend on the specific objectives of nursery and planting system that is used. Every container's main function is to contain the substrate and provide physical support for the plant in the nursery [11]. Features related to the height of the container, the permeability of the walls, and the presence of a drain hole, are important because they affect the relations substrate moisture [11]. All containers have to be durable enough to maintain the structural integrity and contain the radical growth during the nursery period. Also important are properties of resistance, both dry and wet, then all containers must be strong enough to support the substrate and the seedlings during the germination and growth, support irrigation conditions, nursery handling, packaging and transport of seedlings [8].

This research is oriented in two directions:

- Contribute to the reduction of environmental pollution, reusing a fraction of urban solid waste, forestry and agroindustrial waste: newspaper (ONP), office paper (OWP), corrugated cardboard (OCC), pine sawdust, eucalyptus sawdust and sugar cane bagasse as raw material to design biodegradable containers, as an alternative composition to those used nowadays, applying pulp molding technology.

- Evaluate the physical-mechanical properties of secondary fiber pulp combined with sawdust or bagasse fibers, based on laboratory experimentation and optimize the results in order to select an ideal combination of materials that allows the design of pulp molded biocontainers, with a stiff, strong and permeable structure, suitable for plants growing.

The molding technology is an alternative of revaluation of recycled lignocellulosic materials [12, 13]. It allows us to design products of semi-stiff structure, three-dimensional, of varied forms and for various uses. The forming process admits different grades of pulp, which turns it into an attractive resource for the use of recycled lignocellulosic raw materials. However, to achieve this use, one must know how the different materials behave and interact and what features these impart to the final product.

Characterization studies and evaluation of properties of molded pulp products are scarce due to the absence of specific evaluation rules and are generally limited to those using recycled paper as raw material. Evaluation studies dealing with compressive strength and damping capacity to physical shock or vibration, measured as resistance to compression static, dynamic and transmission respectively, testing molded products [14-18] were found. Also were found evaluation studies density, stiffness, tensile strength, bursting strength and tearing strength, measured by applying analytical techniques of physical tests of pulp and paper, testing handsheets $150 \mathrm{~g} / \mathrm{m}^{2}$ basis weight [19, 20].

The molded pulp has the ability to absorb and to cushion shock, ensuring protection of the product that covers handling, transportation or storage. It has the ability to maintain aeration because of its microporousstructure, and it has the ability to absorb moisture because of its chemical structure.

Lignocellulosic fibers have unique qualities that allow them to be used for a variety of structural products. The type of fiber, the individual properties of each fiber and formation characteristics and structural functionality of it, by influencing the characteristics of the final product [21, 22]. For example, softwoods are characterized by long fibers, thin walled, while hardwoods are characterized by short fibers, of thick walls. Long fibers develop 
strength and flexibility which are important for the mechanical properties and to achieve good formation. Short fibers have low tear strength, they cannot be used in high percentages in materials requiring high strength, allowing the obtaining of more rigid products [23].

Using an experimental design of mixtures [24], we can establish combinations of the raw materials source of study and evaluate their behavior considering the needs of the product. This can be done by testing of handsheets, measuring properties of density, dry and wet tensile strength, bursting, compression and tearing, stiffness, permeability and water retention capacity, according to the specific analytical techniques for physical tests of pulp and paper. The density is an indicator of the degree of compaction of the fibers and relative binding area between the fibers. The strength properties are indicative of the degree of individual strength of fiber and the strength of inter-fiber bonds. The degree of water retention is indicative of the ability of the fibers to absorb water and is related to the ability of the fiber to develop strength. Permeability, is indicative of the porosity or void fraction of the material [22].When the intention is to develop materials that must conform to certain properties, it is essential to use tools based on optimization criteria. The mixtures optimization is a systematic activity that aims at all the mixtures of the experimental matrix [24]. With the application of these tools, it will be possible to select suitable raw materials and the proportions among them, obtaining a mixture that satisfies specific technical requirements.

For the development of research it is supposed that:

- Recycled lignocellulosic materials will be components functionally attractive to design biocontainers.

- ONP pulps will give biocontainers of stiff and permeable walls.

- OWP pulps will give biocontainers of strong walls that are resistant to tensile, bursting and compression.
- OCC pulp will give biocontainers of strong walls that are resistant to tearing.

- Pine sawdust, eucalyptus sawdust and bagasse pulp will give biocontainers of highly permeable walls.

The aim of this work is to evaluate the effects of the combination of lignocellulosic materials, secondary fibers alone and mixed with pine sawdust, eucalyptus sawdust and bagasse fibers, on the physical-mechanical properties and to optimize variable responses in order to select an ideal combination to design molded products suitable for plant cultivation.

\section{Materials and Methods}

\subsection{Raw Material}

\subsubsection{Secondary Pulps}

The dry material, recycled paper of type ONP, OWP and OCC, was cut manually and was disintegrated in a "pulper" $8 \%$ consistency. Then the fibrous suspension obtained was screened using equipment with a slotted plate of $5 \mathrm{~mm}$ to remove contaminating particles present in the pulp. The process was carried out individually for each material under study.

\subsubsection{Wood Sawdust}

The dried material, pine sawdust and eucalyptus sawdust, was sieved using a series of standard laboratory sieves of different mesh sizes: 10, 5, 3, $1.410,0.841,0.420$ and $0.250 \mathrm{~mm}$. With each fraction handsheets of $150 \mathrm{~g} / \mathrm{m}^{2}$ basis weight were formed to evaluate the formability and, from this, to select the optimal fraction. Considering the formability of such sheets and higher yielding fractions, the 40-60 mesh fraction was selected. The process was carried out individually for each study material.

\subsubsection{Bagasse Pulp}

The dry material sugarcane bagasse with medulla was disintegrated in a disc refiner. It was worked with three openings of discs: $0.64,0.13$ and $0.05 \mathrm{~mm}$. With each fraction handsheets of $150 \mathrm{~g} / \mathrm{m}^{2}$ basis weight were 
formed to evaluate the formability and, from this, to select the optimal fraction. Considering the formability of such sheets, the $0.05 \mathrm{~mm}$ fraction was selected.

\subsection{Experimental Design}

An experimental design of mixed type with a model of extreme vertices was planned with the help of a statistical program. An experimental matrix for each reinforcing material used was raised given the restrictions in Table 1. Each experimental matrix was formed by 26 different experimental mixtures; made up of 4 components (ONP pulp, OWP pulp, OCC pulp, reinforcing material) and 9 responses variables (density, tensile, wet tensile, bursting, tearing, compression, stiffness, permeability and water retention capacity). The experimental matrix basis is detailed in Table 2.

\subsection{Physical-Mechanical Properties}

To characterize and correlate the materials, the

Table 1 Restrictions for each experimental matrix.

\begin{tabular}{lllll}
\hline Level (\%) & & \multicolumn{3}{c}{ Components } \\
\hline Low & High & Design I & Design II & Design III \\
\hline 0 & 100 & ONP pulp $\left(\mathrm{X}_{1}\right)$ & ONP pulp $\left(\mathrm{X}_{1}\right)$ & ONP pulp $\left(\mathrm{X}_{1}\right)$ \\
0 & 100 & OWP pulp $\left(\mathrm{X}_{2}\right)$ & OWP pulp $\left(\mathrm{X}_{2}\right)$ & OWP pulp $\left(\mathrm{X}_{2}\right)$ \\
0 & 100 & OCC pulp $\left(\mathrm{X}_{3}\right)$ & OCC pulp $\left(\mathrm{X}_{3}\right)$ & OCC pulp $\left(\mathrm{X}_{3}\right)$ \\
0 & 40 & Pine sawdust $\left(\mathrm{X}_{4}\right)$ & Eucalyptus sawdust $\left(\mathrm{X}_{4}\right)$ & Bagasse pulp $\left(\mathrm{X}_{4}\right)$ \\
$\mathrm{X}_{1}+\mathrm{X}_{2}+\mathrm{X}_{3}+\mathrm{X}_{4}=100 \%$ & & & \\
\hline
\end{tabular}

Table 2 Experimental matrix basis.

\begin{tabular}{|c|c|c|c|c|}
\hline Experimental mixture & $\mathrm{X}_{1}(\%)$ & $\mathrm{X}_{2}(\%)$ & $\mathrm{X}_{3}(\%)$ & $\mathrm{X}_{4}(\%)$ \\
\hline 1 & 100.0 & 0.0 & 0.0 & 0.0 \\
\hline 2 & 0.0 & 100.0 & 0.0 & 0.0 \\
\hline 3 & 0.0 & 0.0 & 100.0 & 0.0 \\
\hline 4 & 60.0 & 0.0 & 0.0 & 40.0 \\
\hline 5 & 0.0 & 60.0 & 0.0 & 40.0 \\
\hline 6 & 0.0 & 0.0 & 60.0 & 40.0 \\
\hline 7 & 63.3333 & 13.3333 & 13.3333 & 10.0 \\
\hline 8 & 13.3333 & 63.3333 & 13.3333 & 10.0 \\
\hline 9 & 13.3333 & 13.3333 & 63.3333 & 10.0 \\
\hline 10 & 43.3333 & 13.3333 & 13.3333 & 30.0 \\
\hline 11 & 13.3333 & 43.3333 & 13.3333 & 30.0 \\
\hline 12 & 13.3333 & 13.3333 & 43.3333 & 30.0 \\
\hline 13 & 50.0 & 50.0 & 0.0 & 0.0 \\
\hline 14 & 50.0 & 0.0 & 50.0 & 0.0 \\
\hline 15 & 80.0 & 0.0 & 0.0 & 20.0 \\
\hline 16 & 0.0 & 50.0 & 50.0 & 0.0 \\
\hline 17 & 0.0 & 80.0 & 0.0 & 20.0 \\
\hline 18 & 0.0 & 0.0 & 80.0 & 20.0 \\
\hline 19 & 30.0 & 30.0 & 0.0 & 40.0 \\
\hline 20 & 30.0 & 0.0 & 30.0 & 40.0 \\
\hline 21 & 0.0 & 30.0 & 30.0 & 40.0 \\
\hline 22 & 33.3333 & 33.3333 & 33.3333 & 0.0 \\
\hline 23 & 40.0 & 40.0 & 0.0 & 20.0 \\
\hline 24 & 40.0 & 0.0 & 40.0 & 20.0 \\
\hline 25 & 0.0 & 40.0 & 40.0 & 20.0 \\
\hline 26 & 20.0 & 20.0 & 20.0 & 40.0 \\
\hline
\end{tabular}


following properties were evaluated: Apparent density (TAPPI 220 sp-96); Tensile breaking (TAPPI 494 om-96); Burstingstrength (TAPPI 807 om-99); Tearing resistance (TAPPI 414 om-98); Ring crush RCT (TAPPI $818 \mathrm{~cm}-97$ ); Wet tensile breaking (TAPPI 456 wd-97), Stiffness (TAPPI 489 om-99), Air resistance (TAPPI 460 om-96) and Water retention capacity WRV (ISO 23714), testing handsheets of more weight, $150 \mathrm{~g} / \mathrm{m}^{2}$ elaborated according to TAPPI 205 sp-95, considering the experimental matrix.

\subsection{Experimental Optimization Mixtures}

The data were evaluated according to the experimental plan, with the help of a statistical program. The combination of experimental factors that simultaneously improve performance of the properties by optimizing individual responses or through multiple responses was determined. Considering the technical requirements (strong materials, stiff materials and permeable materials), mixtures optimization was carried out under the following criteria:

- Maximize mechanical strength properties.

- Maximize stiffness properties.

- Minimize air resistance (maximize permeability). In order to optimize, firstly, individual variables responses were adjusted to a mathematical model, considering the statistically significant effects at $95 \%$. Then, the multiple responses were optimized to determine the combination of factor levels that reach the global optimal "desirability" and values of experimental factors that maximize the desirability function.

\section{Results and Discussion}

\subsection{Adjusted Model}

For the evaluation of each response variable, the most complicated model for which the p-value is less than 0.05 was selected, indicating that there is a statistically significant relationship between response variables and components at a confidence level of $95 \%$. The best model corresponds to a polynomial relationship, with the smallest standard error and the highest R-Square adjusted. The equations of the adjusted model, for each of the variables, are shown in Table 3.

As from the Table 3, it is observed that the polynomial equations of the responses variable of each of the designs include pure or binary mixtures, except WRV responses, that in addition they include ternary mixtures.

The results of polynomial equations indicate the influence of each component in the response. The pure component of higher value is the one that has a greater influence on the response. In combined effects, a positive sign implies synergistic effect between the components, that is to say, it will have a greater response when these components are mixed. By contrast, a negative sign implies an antagonistic effect between the components, that is to say, minor responses when these components will mix [24].

The OWP pure component has more influence on density, tensile index, bursting index, RCT, air resistance and WRV. The OCC pure component has more influence on tearing index and wet tensile index. The ONP pure component has more influence on stiffness. The reinforcement materials have minimal influence on the studied variables. In component interactions, an antagonistic effect is mainly observed. Only in the variable, WRV and stiffness, synergistic effect observed.

\subsection{Optimization Responses}

As from the estimated mathematical model, the combination of experimental factors that optimize the performance of responses variables according to objectives was determined.

The combination of the factor levels of the mixture design that optimizes responses variables individually 
Table 3 Model adjusted for each response variable.

\begin{tabular}{|c|c|c|}
\hline Designs & Adjusted model equation & $\mathrm{R}^{2}$-adjusted (\%) \\
\hline \multirow{9}{*}{ I Design } & $\begin{array}{l}\text { Density }=0.41 * \text { ONP }+0.65 * \text { OWP }+0.54 * \text { OCC }+1.10 * \text { Pine }-1.58 * \text { ONP } * \text { Pine }-2.18 * \text { OWP } * \text { Pine }- \\
1.87 * \text { OCC } * \text { Pine }\end{array}$ & 95.03 \\
\hline & $\begin{array}{l}\text { Tensile index }=14.01 * \text { ONP }+45.25 * \text { OWP }+27.71 * \text { OCC }+14.82 * \text { Pine }-18.02 * \text { ONP*OWP }- \\
39.72 * \text { ONP*Pine }-88.60 * \text { OWP*Pine }-55.89 * \text { OCC } * \text { Pine }\end{array}$ & 98.63 \\
\hline & $\begin{array}{l}\text { Bursting index }=0.43 * \mathrm{ONP}+2.99 * \mathrm{OWP}+1.59 * \mathrm{OCC}+0.11 * \mathrm{Pine}-2.06 * \mathrm{ONP} * \mathrm{OWP}- \\
4.88 * \mathrm{OWP} * \text { Pine }-2.35 * \mathrm{OCC} * \text { Pine }\end{array}$ & 96.18 \\
\hline & $\begin{array}{l}\text { Tearing index }=3.07 * \mathrm{ONP}+8.36 * \mathrm{OWP}+10.41 * \mathrm{OCC}-1.27 * \mathrm{Pine}-2.83 * \mathrm{ONP} * \mathrm{OWP}- \\
4.48 * \mathrm{ONP} * \mathrm{OCC}-8.44 * \mathrm{OCC} * \text { Pine }\end{array}$ & 99.44 \\
\hline & $\begin{array}{l}\mathrm{RCT}=0.87 * \mathrm{ONP}+2.37 * \mathrm{OWP}+1.59 * \mathrm{OCC}+1.75 * \text { Pine }-3.77 * \mathrm{ONP} * \text { Pine }-6.13 * \mathrm{OWP} * \text { Pine }- \\
4.88 * \text { OCC } * \text { Pine }\end{array}$ & 98.40 \\
\hline & $\begin{array}{l}\text { Stiffness }=2.91 * \text { ONP }+1.82 * \text { OWP }+2.04 * \text { OCC }-1.94 * \text { Pine }-1.14 * \text { ONP } * \text { OCC }+5.93 * \text { OWP } * \text { Pine } \\
+4.85 * \text { OCC } * \text { Pine }\end{array}$ & 87.65 \\
\hline & $\begin{array}{l}\text { Wet tensile index }=1.72 * \text { ONP }+1.34 * \mathrm{OWP}+1.86 * \mathrm{OCC}+1.26 * \text { Pine }-1.09 * \mathrm{ONP} * \mathrm{OWP}- \\
3.65 * \text { ONP*Pine }-3.98 * \text { OWP*Pine }-4.10 * \text { OCC } * \text { Pine }\end{array}$ & 95.85 \\
\hline & $\begin{array}{l}\text { Air resistance }=8.83 * \text { ONP }+49.45 * \text { OWP }+11.01 * \text { OCC }+81.94 * \text { Pine }-35.77 * \text { ONP*OWP }- \\
138.00 * \text { ONP } * \text { Pine }-22.60 * \text { OWP } * \text { OCC }-254.60 * \text { OWP*Pine }-148.80 * \text { OCC*Pine }\end{array}$ & 91.40 \\
\hline & $\begin{array}{l}\text { WRV }=1.22 * \text { ONP }+1.26 * \text { OWP }+1.15 * \text { OCC }+0.60 * \text { Pine }+0.38 * \text { ONP } * \text { OWP }+0.22 * \text { ONP } * \text { Pine }+ \\
0.51 * \text { OWP } * \text { Pine }-3.35 * \text { ONP } * \text { OWP } * \text { Pine }\end{array}$ & 91.91 \\
\hline \multirow{9}{*}{ II Design } & $\begin{array}{l}\text { Density }=0.40 * \text { ONP }+0.66 * \text { OWP }+0.54 * \text { OCC }+0.96 * \text { Eucalyptus }-1.33 * \text { ONP*Eucalyptus }- \\
1.93 * \text { OWP*Eucalyptus }-1.67 * \text { OCC } * \text { Eucalyptus }\end{array}$ & 97.02 \\
\hline & $\begin{array}{l}\text { Tensile index }=14.44 * \text { ONP }+45.37 * \text { OWP }+27.46 * \text { OCC }+22.75 * \text { Eucalyptus }-15.74 * \text { ONP*OWP } \\
-52.55 * \text { ONP*Eucalyptus }-95.34 * \text { OWP*Eucalyptus }-65.95 * \text { OCC*Eucalyptus }\end{array}$ & 98.68 \\
\hline & $\begin{array}{l}\text { Bursting index }=0.54 * \mathrm{ONP}+3.00 * \mathrm{OWP}+1.62 * \mathrm{OCC}+2.33 * \text { Eucalyptus }-1.91 * \mathrm{ONP} * \mathrm{OWP}- \\
3.86 * \text { ONP } * \text { Eucalyptus }-8.02 * \text { OWP Eucalyptus }-5.60 * \text { OCC } * \text { Eucalyptus }\end{array}$ & 96.29 \\
\hline & $\begin{array}{l}\text { Tearing index }=2.93 * \text { ONP }+8.19 * \text { OWP }+10.32 * \text { OCC }+5.96 * \text { Eucalyptus }-3.75 * \text { ONP*OCC }- \\
10.35 * \text { ONP*Eucalyptus }-9.97 * \text { OWP*Eucalyptus }-18.94 * \text { OCC*Eucalyptus }\end{array}$ & 96.27 \\
\hline & $\begin{array}{l}\text { RCT }=0.88 * \text { ONP }+2.37 * \text { OWP }+1.57 * \text { OCC }+3.07 * \text { Eucalyptus }-6.06 * \text { ONP*Eucalyptus }- \\
8.43 * \text { OWP*Eucalyptus }-6.99 * \text { OCC*Eucalyptus }\end{array}$ & 97.83 \\
\hline & $\begin{array}{l}\text { Stiffness }=2.82 * \text { ONP }+1.85 * \text { OWP }+1.96 * \text { OCC }+1.03 * \text { Eucalyptus }-0.76 * \text { ONP*OCC }- \\
4.70 * \text { ONP*Eucalyptus }+1.67 * \text { OWP } * \text { Eucalyptus }\end{array}$ & 87.41 \\
\hline & $\begin{array}{l}\text { Wet tensile index }=1.67 * \text { ONP }+1.35^{*} \text { OWP }+1.85^{*} \text { OCC }+4.69 * \text { Eucalyptus }-1.11 * \text { ONP*OWP }- \\
10.05^{*} \text { ONP*Eucalyptus }-9.38 * \text { OWP }{ }^{*} \text { Eucalyptus }-10.64 * \text { OCC }{ }^{*} \text { Eucalyptus }\end{array}$ & 94.10 \\
\hline & $\begin{array}{l}\text { Air resistance }=9.42 * \text { ONP }+48.36 * \text { OWP }+8.66 * \text { OCC }+72.20 * \text { Eucalyptus }-29.67 * \text { ONP*OWP }- \\
122.70 * \text { ONP*Eucalyptus }-241.10 * \text { OWP*Eucalyptus }-132.60 * \text { OCC } * \text { Eucalyptus }\end{array}$ & 90.98 \\
\hline & $\begin{array}{l}\text { WRV }=1.22 * \text { ONP }+1.29 * \text { OWP }+1.15 * \text { OCC }+1.02 * \text { Eucalyptus }+0.23 * \text { ONP } * \text { OWP }- \\
0.71 * \text { ONP*Eucalyptus }-0.66 * \text { OWP } * \text { Eucalyptus }\end{array}$ & 76.14 \\
\hline \multirow{9}{*}{ III Design } & $\begin{array}{l}\text { Density }=0.41 * \text { ONP }+0.66 * \text { OWP }+0.54 * \text { OCC }+0.57 * \text { Bagasse }-0.45 * \text { ONP*Bagasse }- \\
0.94 * \text { OWP*Bagasse }-0.69 * \text { OCC } * \text { Bagasse }\end{array}$ & 95.28 \\
\hline & $\begin{array}{l}\text { Tensile index }=15.20 * \text { ONP }+45.49 * \text { OWP }+27.63 * \text { OCC }-5.11 * \text { Bagasse }-17.49 * \text { ONP } * \text { OWP }- \\
7.94 * \text { ONP*OCC }-28.44 * \text { OWP } * \text { Bagasse }\end{array}$ & 98.70 \\
\hline & $\begin{array}{l}\text { Bursting index }=0.48 * \mathrm{ONP}+3.03 * \mathrm{OWP}+1.63 * \mathrm{OCC}+0.18 * \text { Bagasse }-1.94 * \mathrm{ONP} * \mathrm{OWP}- \\
3.80 * \mathrm{OWP} * \text { Bagasse }-1.63 * \text { OCC } * \text { Bagasse }\end{array}$ & 97.08 \\
\hline & $\begin{array}{l}\text { Tearing index }=2.99 * \mathrm{ONP}+8.40 * \mathrm{OWP}+10.47 * \mathrm{OCC}+0.27 * \text { Bagasse }-2.65 * \mathrm{ONP} * \mathrm{OWP}- \\
4.05 * \text { ONP*OCC }-6.56 * \text { OCC } * \text { Bagasse }\end{array}$ & 99.04 \\
\hline & $\begin{array}{l}\mathrm{RCT}=0.94 * \mathrm{ONP}+2.41 * \mathrm{OWP}+1.66 * \mathrm{OCC}+0.17 * \text { Bagasse }-0.47 * \mathrm{ONP} * \mathrm{OWP}-0.62 * \mathrm{ONP} * \mathrm{OCC} \\
-0.95 * \text { OWP } * \text { Bagasse }-0.53 * \text { OCC } * \text { Bagasse }\end{array}$ & 98.92 \\
\hline & $\begin{array}{l}\text { Stiffness }=2.77 * \text { ONP }+1.82 * \text { OWP }+2.03 * \text { OCC }+0.27 * \text { Bagasse }-0.97 * \text { ONP } * \text { OCC }+ \\
4.50 * \text { OWP } * \text { Bagasse }+3.68 * \text { OCC } * \text { Bagasse }\end{array}$ & 57.08 \\
\hline & $\begin{array}{l}\text { Wet tensile index }=1.61 * \mathrm{ONP}+1.25 * \mathrm{OWP}+1.91 * \mathrm{OCC}+3.74 * \text { Bagasse }-7.86 * \mathrm{ONP} * \text { Bagasse }- \\
6.78 * \text { OWP } * \text { Bagasse }-8.14 * \mathrm{OCC} * \text { Bagasse }\end{array}$ & 86.40 \\
\hline & $\begin{array}{l}\text { Air resistance }=7.78 * \text { ONP }+50.43 * \text { OWP }+9.04 * \text { OCC }-0.67 * \text { Bagasse }-35.71 * \text { ONP*OWP }- \\
21.51 * \text { OWP*OCC }-99.51 * \text { OWP*Bagasse }\end{array}$ & 94.13 \\
\hline & $\begin{array}{l}\text { WRV }=1.24 * \text { ONP }+1.29 * \text { OWP }+1.15 * \text { OCC }+1.01 * \text { Bagasse }+0.24 * \text { ONP } * \text { OWP }- \\
0.05 * \text { ONP } * \text { OCC }-0.10 * \text { ONP*Bagasse }+0.05 * \text { OWP } * \text { OCC }-0.18 * \text { OWP } * \text { Bagasse }+ \\
0.11 * \text { OCC } * \text { Bagasse }+2.55 * \text { ONP } * \text { OCC } * \text { Bagasse }\end{array}$ & 53.37 \\
\hline
\end{tabular}


Table 4 Combination of levels of experimental factors that optimize responses.

\begin{tabular}{|c|c|c|c|c|c|}
\hline \multirow{2}{*}{ Responses } & \multirow{2}{*}{ Units } & \multirow{2}{*}{ Objective } & \multicolumn{3}{|c|}{ Optimum factor levels (\%) } \\
\hline & & & I Design & II Design & III Design \\
\hline Density & $\mathrm{g} / \mathrm{cm}^{3}$ & Maximizar & 100 OWP & 100 OWP & 100 OWP \\
\hline Tensile index & $\mathrm{N} \cdot \mathrm{m} / \mathrm{g}$ & Maximizar & 100 OWP & 100 OWP & 100 OWP \\
\hline Bursting index & $\mathrm{kPa} \cdot \mathrm{m}^{2} / \mathrm{g}$ & Maximizar & 100 OWP & 100 OWP & 100 OWP \\
\hline Tearing index & $\mathrm{mN} \cdot \mathrm{m}^{2} / \mathrm{g}$ & Maximizar & 100 OCC & 100 OCC & 100 OCC \\
\hline RCT & $\mathrm{kN} / \mathrm{m}$ & Maximizar & 100 OWP & 100 OWP & 100 OWP \\
\hline Stiffness & $\mathrm{mN} \cdot \mathrm{m}$ & Maximizar & 100 ONP & 100 ONP & 100 ONP \\
\hline Wet tensile index & $\mathrm{N} \cdot \mathrm{m} / \mathrm{g}$ & Maximizar & 100 OCC & 100 OCC & 100 OCC \\
\hline Air resistance & $\mathrm{s}$ & Minimizar & $\begin{array}{l}30 \text { / } 30 \text { /40 } \\
\text { ONP / OWP / Pine }\end{array}$ & $\begin{array}{l}30 / 30 \text { /40 } \\
\text { ONP / OWP / } \\
\text { Eucalyptus }\end{array}$ & $\begin{array}{l}30 / 30 \text { /40 } \\
\text { ONP / OWP / } \\
\text { Bagasse }\end{array}$ \\
\hline WRV & $\mathrm{g} / \mathrm{g}$ & Maximizar & $\begin{array}{l}50 / 50 \\
\text { ONP / OWP }\end{array}$ & $\begin{array}{l}50 / 50 \\
\text { ONP / OWP }\end{array}$ & $\begin{array}{l}50 \text { / } 50 \\
\text { ONP / OWP }\end{array}$ \\
\hline Multiple responses & & According objectives & $\begin{array}{l}50 / 50 \\
\text { OWP / OCC }\end{array}$ & $\begin{array}{l}50 \text { / } 50 \\
\text { OWP / OCC }\end{array}$ & $\begin{array}{l}50 \text { / } 50 \\
\text { OWP / OCC }\end{array}$ \\
\hline
\end{tabular}

and the combination of level of the factor of the mixture design that optimizes all responses variable simultaneously, are indicated in Table 4.

As from Table 4, it is observed that the factor of the mixture design that optimizes the responses individually: density, tensile index, bursting index and RCT corresponds to OWP pulps. The factor of the mixture design that optimizes the responses individually: tearing index and wet tensile index corresponds to OCC pulps. The factor of the mixture design that optimizes the response individually: stiffness corresponds to ONP pulps. The factor of the mixture design that optimizes the response individually: air resistance corresponds to a combination of ONP/OWP/reinforcing material in a 30/30/40 proportion. The factor of the mixture design that optimizes the response individually: WRV corresponds to the combination of ONP/OWP in a $50 / 50$ proportion.

The factor of the mixture design that optimizes all responses simultaneously, considering the maximum "desirability", corresponds to the combination of OWP/OCC in a 50/50 proportion. It is assumed that such combination allows the obtaining of biocontainers of quality in terms of strength, stiffness and permeability of the material.

The results show that: OWP and OCC pulps maximize the strength properties and ONP pulps maximize stiffness properties and reinforcing materials maximize the permeability properties of the product.

The results did not vary by varying the reinforcing material used, which shows that the secondary fibers have a greater influence on the properties analyzed.

When multiple responses are studied, there are two alternative analysis, analyze each response individually or analyze each response simultaneously [25]. But when the responses are correlated, if an individual analysis of each response is carried out, it can lead to unsatisfactory results: different recommendations as regards the combination of important components or the loss of the opportunity to find a combination of components that together will improve the quality of all responses studied.

The results show that the factors influence differently on each variable. The factors that optimize the individual variables and the factors those that optimize the multiple variables differ from each other one from another.

While designing containers from fibrous materials is increasing, no studies to apply the same assessment methodology were found, which made the discussion of the results obtained, difficult.

\subsection{Multiple Response Values Optimized}

With the process of multivariable optimization, it 
was found that the combination of factor levels at which, the optimum is achieved is the mixture of OWP/OCC in a 50/50 proportion.

To this optimum point of the experimental design, the values achieved by each of the variables analyzed were determined.

The minimum, maximum and optimum values for each of the variables to the combination of factors that optimize the multiple responses are detailed in Table 5.

As from Table 5, it is observed that minimum, maximum and optimum values for each response variable studied do not show significant variation between different experimental designs.

As for the structure of the composite, the mechanical strength properties are of great importance, because regardless of the specific product application, they must meet certain characteristics with respect to shape, hardness, and resistance.

Comparison and correlation of the results obtained in this investigation with those achieved by other authors is scarce because, we did not find authors that use the same methodology of design or evaluation of properties.

Nechita et al. [26] evaluated the properties of breaking and tearing strength in secondary fibers of OCC testing sheets. Although the methodology is different, the results achieved in terms of breaking are equivalent to those found in this research, while tear values are lower than those found in this research. In

Table 5 Multiple response values optimized.

\begin{tabular}{|c|c|c|c|c|c|c|c|c|}
\hline \multirow{2}{*}{ Responses } & \multirow{2}{*}{ Units } & \multirow{2}{*}{ Observed } & \multicolumn{2}{|c|}{ I Design } & \multicolumn{2}{|c|}{ II Design } & \multicolumn{2}{|c|}{ III Design } \\
\hline & & & Value & $\mathrm{N}^{\circ}$ run & Value & $\mathrm{N}^{\circ}$ run & Value & $\mathrm{N}^{\circ}$ run \\
\hline \multirow{3}{*}{ Density } & \multirow{3}{*}{$\mathrm{g} / \mathrm{cm}^{3}$} & Minimum & 0.28 & 4 & 0.29 & 4 & 0.35 & 4 \\
\hline & & Maximum & 0.69 & 2 & 0.69 & 2 & 0.69 & 2 \\
\hline & & Optimum & 0.59 & 16 & 0.60 & 16 & 0.60 & 16 \\
\hline \multirow{3}{*}{ Tensile index } & \multirow{3}{*}{$\mathrm{N} \mathrm{m} / \mathrm{g}$} & Minimum & 3.83 & 4 & 4.40 & 4 & 7.46 & 4 \\
\hline & & Maximum & 46.57 & 2 & 46.57 & 2 & 46.57 & 2 \\
\hline & & Optimum & 36.48 & 16 & 36.42 & 16 & 36.56 & 16 \\
\hline \multirow{3}{*}{ Bursting index } & \multirow{3}{*}{$\mathrm{kPa} \cdot \mathrm{m}^{2} / \mathrm{g}$} & Minimum & 0.20 & 4 & 0.22 & 4 & 0.30 & 4 \\
\hline & & Maximum & 3.20 & 2 & 3.20 & 2 & 3.20 & 2 \\
\hline & & Optimum & 2.29 & 16 & 2.31 & 16 & 2.33 & 16 \\
\hline \multirow{3}{*}{ Tearing index } & \multirow{3}{*}{$\mathrm{mN} \cdot \mathrm{m}^{2} / \mathrm{g}$} & Minimum & 1.32 & 4 & 1.60 & 4 & 1.86 & 4 \\
\hline & & Maximum & 10.42 & 3 & 10.42 & 3 & 10.42 & 3 \\
\hline & & Optimum & 9.38 & 16 & 9.26 & 16 & 9.44 & 16 \\
\hline \multirow{3}{*}{ RCT } & \multirow{3}{*}{$\mathrm{kN} / \mathrm{m}$} & Minimum & 0.28 & 4 & 0.25 & 4 & 0.58 & 4 \\
\hline & & Maximum & 2.42 & 2 & 2.42 & 2 & 2.42 & 2 \\
\hline & & Optimum & 1.98 & 16 & 1.97 & 16 & 2.04 & 16 \\
\hline \multirow{3}{*}{ Stiffness } & \multirow{3}{*}{$\mathrm{mN} \cdot \mathrm{m}$} & Minimum & 1.01 & 4 & 0.78 & 4 & 1.73 & 4 \\
\hline & & Maximum & 2.93 & 1 & 2.93 & 1 & 2.93 & 1 \\
\hline & & Optimum & 1.93 & 16 & 1.91 & 16 & 1.93 & 16 \\
\hline \multirow{3}{*}{$\begin{array}{l}\text { Wet tensile } \\
\text { index }\end{array}$} & \multirow{3}{*}{$\mathrm{N} \cdot \mathrm{m} / \mathrm{g}$} & Minimum & 0.28 & 5 & 0.32 & 19 & 0.40 & 20 \\
\hline & & Maximum & 1.97 & 3 & 1.97 & 3 & 1.97 & 3 \\
\hline & & Optimum & 1.60 & 16 & 1.60 & 16 & 1.58 & 16 \\
\hline \multirow{3}{*}{ Air resistance } & \multirow{3}{*}{ s } & Minimum & 1.30 & 26 & 1.22 & 26 & 3.13 & 4 \\
\hline & & Maximum & 54.94 & 2 & 54.94 & 2 & 54.94 & 2 \\
\hline & & Optimum & 24.58 & 16 & 28.51 & 16 & 24.36 & 16 \\
\hline \multirow{3}{*}{ WRV } & \multirow{3}{*}{$\mathrm{g} / \mathrm{g}$} & Minimum & 0.95 & 6 & 0.97 & 4 & 1.11 & 6 \\
\hline & & Maximum & 1.35 & 13 & 1.35 & 13 & 1.35 & 13 \\
\hline & & Optimum & 1.20 & 16 & 1.22 & 16 & 1.23 & 16 \\
\hline
\end{tabular}


addition, they designed biocontainers with mixtures: peat/cellulose fiber/chemical load; peat/cellulosic fiber/waste processing grapes; peat/cellulosic fibers and they evaluated strength of penetration and found that the resistance achieved by these mixtures (40, 60 and $110 \mathrm{~N}$, respectively) is higher than that required for the process of seedling production.

Yamauchi et al.[27], evaluated the mechanical strength, tensile and lateral and longitudinal compression in biocontainers made of ONP secondary fibers, and found higher values than those found in this investigation.

Evans et al. [3] evaluated vertical strength, lateral strength and punch strength in dry in plastic containers and various commercial biocontainers with a base of paper, coconut fiber, peat, rice hull, among other. The rice hull biocontainers had higher vertical and lateral strength than paper and plastic biocontainers, which had similar strength. The other biocontainers had a lower strength. The plastic, paper, rice hull and coconut fiber containers had the highest punch strength of all the containers evaluated. They concluded that the highest strengths are achieved with walls of greater stiffness, thickness and porosity.

Beeks et al. [8] evaluated punch strength in plastic containers and various commercial biocontainers with a base of paper, wood fiber, rice straw, dairy manure, coconut fiber, peat, among other. They found that the coconut fiber and paper biocontainers had similar and higher strength of all the other biocontainers evaluated.

\section{Conclusions}

From the analysis it is concluded that:

- Mixtures of ONP pulps in a $100 \%$ proportion will allow the design of biocontainers of stiff and permeable structure.

- Mixtures of OWP pulps in a $100 \%$ proportion, will allow the design of biocontainers of strong walls resistant to tensile breaking, bursting and compression.
- Mixtures of OCC pulp in a $100 \%$ proportion, will allow the design of biocontainers of strong walls resistant to tearing and wet tensile.

- Mixtures of pulps with wood sawdust or bagasse fibers, will allow the design of biocontainers with walls of low mechanical strength and of a significantly permeable structure.

- Recycled lignocellulosic materials are suitable to design biocontainers of molded pulp.

- The mixture of pulp OWP/OCC in a 50/50 proportion corresponds to the ideal mixture to design biocontainers of strong, stiff and permeable structure.

- In a later work, biocontainers with the optimized mixtures will be designed. It will measure the physical-mechanical properties and the results will be correlated with the values obtained by this research.

\section{Acknowledgements}

The authors gratefully acknowledge Mr. Fernando Esteban Felissia for your cooperation. Dr. in Technical Sciences, Professor and Researcher at the Faculty of Exact, Chemical and Natural Sciences, National University of Misiones; Investigating member of the Institute of Materials Misiones of double dependence UNaM-CONICET. ffelissia@gmail.com

This research was financed for Project of technological and social development: PDTS CIN-CONICET (Resolution No 271/14).

\section{Reference}

[1] Beeks, S. A. and Evans, M. R. 2013. "Growth of Cyclamen in Biocontainers on an Ebb-and-Flood Subirrigation System.” HortTechnology 23 (April): 173-6.

[2] Evans, M. R. and Hensley, D. L. 2004. "Plant Growth in Plastic, Peat, and Processed Poultry Feather Fiber Growing Containers.” HortScience 39 (5): 1012-4.

[3] Evans, M. R., Taylor, M. and Kuehny, J. 2010. "Physical Properties of Biocontainers for Greenhouse Crops Production.” HortTechnology 20 (3): 549-55.

[4] Mooney, B. P. 2009. "The Second Green Revolution? Production of Plant-Based Biodegradable Plastics.” Biochem. J. 418 (2): 219-32. 
[5] Evans, M. R., Koeser, A. K., Bi, G., Nambuthiri, S., Geneve, R. and Lovell, S. T. et al. 2015. "Impact of Biocontainers with and without Shuttle Trays on Water Use in the Production of a Containerized Ornamental Greenhouse Crop.” HortTechnology 25 (1): 35-41.

[6] Landis, T. D., Tinus, R. W., McDonald, S. E. and Barnett, J. P. 1990. Containers and Growing Media. The Container Tree Nursery Manual: Volume 2, Agric. Handbk. 674. Department of Agriculture, Forest Service, Washington.

[7] Lina, W., Toshio, M., Yo-Ichi, M., Yoshiaki, A. and Yasuharu, T. 2013. "Development of Biodegradable Seedling Pot Using Konjac by- Product of Industrial Waste.” J. Text. Eng. 59 (3): 43-9.

[8] Beeks, S. A. and Evans, M. R. 2013. "Physical Properties of Biocontainers Used to Grow Long-Term Greenhouse Crops in an Ebb-and-Flood Irrigation System.” HortScience 48 (6): 732-7.

[9] Evans, M. R. and Karcher, D. 2004. "Properties of Plastic, Peat, and Processed Poultry Feather Fiber Growing Containers.” HortScience 39 (5): 1008-11.

[10] Castronuovo, D., Picuno, P., Manera, C., Scopa, A., Sofo, A. and Candido, V. 2015. "Biodegradable Pots for Poinsettia Cultivation: Agronomic and Technical Traits.” Sci. Hortic. 197: 150-6.

[11] Landis, T. D., Dumroese, R. K. and Haase, D. L. 2010. Seedling Processing, Storage, and Outplanting. The Container Tree Nursery Manual: Volume 7, Agric. Handbk. 674. Department of Agriculture, Forest Service, Washington.

[12] Paine, F. A. 1991. "Moulded Pulp, Expanded Polystyrene, Moulded and Thermoformed Plastic Containers.” In The Packaging User's Handbook. 1th Ed. Paine, F. A. (Ed.), Chapman\&Hall, Glasgow.

[13] Hogarth, C. 2005. "Moulded Pulp Packaging.” In Paper and Paperboard. Packaging Technology. 1th ed. Kirwan, M. J. (Ed.), Blackwell Publishing Ltd, London.

[14] Eagleton, D. G. and Marcondes, J. A. 1994. "Cushioning Properties of Moulded Pulp.” Packag. Technol. Sci. 7: 65-72.

[15] Hoffmann, J. 2000. "Compression and Cushioning Characteristics of Moulded Pulp Packaging.” Packag.
Technol. Sci. 13 (5): 211-20.

[16] Wang, Z. W. and Li, X. F. 2014. "Effect of Strain Rate on Cushioning Properties of Molded Pulp Products.” Mater. Des.57: 598-607.

[17] Ji, H., Wang, H. and Chen, J. 2008. "Mechanical Behaviors of Molded Pulp Material.” In International Conference on Experimental Mechnics 2008 and Seventh Asian Conference on Experimental Mechanics. International Society for Optics and Photonics, 73756D.

[18] Gurav, S. P., Bereznitski, A., Heidweiller, A. and Kandachar, P. V. 2003. "Mechanical Properties of Paper-Pulp Packaging.” Compos. Sci. Technol. 63 (9): 1325-34.

[19] Gavazzo, G. B., Lanouette, R. and Valade, J. L. 2005. "Production of Molded Pulp at Laboratory Scale." Prog. Pap. Recycl. 14 (2): 20-5.

[20] Gavazzo, G. B. and Pavlik, C. A. 2008. "Influence of Raw Material in the Pulps Molding Operation and Properties of the Final Product.” In V Iberoamerican Congress on Pulp and Paper Research.

[21] Howard, R. C. and Bichard, W. 1992. "The Basic Effects of Recycling on Pulp Properties.” J. pulp Pap. Sci. 18 (4): 151-9.

[22] Biermann, C. J. 1996. Handbook of Pulping and Papermaking. 2th Ed. Academic Press Limited, London.

[23] PendlePace Ltd. 2005. UK Market Review of Moulded Paper Pulp Executive summary. The Waste \&Resources Action Programme, Banbury.

[24] Montgomery, D. C. 2004. Design and analysis of experiments. 2th Ed. Limusa S.A., México.

[25] Limón, J., Rodriguez, M. A., Sánchez, J., and Tlapa, D. A. 2012. "Bayesian Methods for Simultaneous Optimizationof Ultiple Responses.” Inf. Tecnol. 23 (2): 151-66.

[26] Nechita, P., Dobrin, E., Ciolacu, F. and Bobu, E. 2010. "The Biodegradability and Mechanical Strength of Nutritive Pots for Vegetable Planting Based on Lignocellulose Composite Materials.” BioResources 5 (7): 1102-13.

[27] Yamauchi, M., Masuda, S. and Kihara, M. 2006. "Recycled Pots Using Sweet Potato Distillation Lees." Resour. Conserv. Recycl. 47 (2): 183-94. 